\title{
Potentialities of human rights: Agamben and the narrative of fated necessity
}

\author{
Ayten Gündoğdu \\ Department of Political Science, Barnard College-Columbia University, New York, \\ NY 10027-6598, USA. \\ agundogdu@barnard.edu
}

\begin{abstract}
Giorgio Agamben presents us with one of the most powerful and controversial criticisms of human rights. He contests conventional understandings of human rights as normative setbacks on sovereign power, and shows instead how these rights reinforce sovereignty by producing bare lives that are irredeemably exposed to violence. This essay aims to understand the distinctive aspects of Agamben's critique and assess his concluding call for a politics beyond human rights. It suggests that this call is necessitated by a counternarrative of Western politics that ties human rights inextricably to the logic Agamben ascribes to biopolitical sovereignty. Within this stringent logic, any politics organized around human rights cannot help but reproduce sovereign violence. The essay questions this counternarrative in two ways: First, it shows how this counternarrative, which aims to unveil all the myths that sustain sovereignty, ends up repeating what it identifies as the distinctive mythologizing gesture: rendering the contingent necessary. Second, it turns to Agamben's notion of 'potentiality' to break the binding spell of his narrative of fated necessity and reclaim the contingent, equivocal and unpredictable effects of modern rights declarations and struggles. The essay concludes with a discussion of contemporary rights struggles of sans-papiers to illustrate the strengths and limits of Agamben's critique of human rights.

Contemporary Political Theory (2012) 11, 2-22. doi:10.1057/cpt.2010.45; published online 19 July 2011
\end{abstract}

Keywords: Agamben; human rights; sovereignty; biopolitics; potentiality; sans-papiers

Human rights have become a predominant discourse in global politics particularly in the post-Cold War era as they have been invoked to address multifarious forms of injustice ranging from violence against women to global

(C) 2012 Macmillan Publishers Ltd. 1470-8914 Contemporary Political Theory Vol. 11, 1, 2-22 www.palgrave-journals.com/cpt/ 
poverty. If this transformation has been welcome by some for its promise of a cosmopolitan future, it has also become the target of several critics who underline the insidious effects of human rights as a new form of power. The cosmopolitan aura of human rights has been increasingly demystified as various scholars have pointed out their deployment in the justification of neoimperial interventions (Anderson, 2002; Mutua, 2002; Douzinas, 2007), their masking of a political power constituting subjects in need of political protection (Brown, 2004), and their hegemonic hold on our political imagination (Kennedy, 2002).

Giorgio Agamben makes a distinctive contribution to this contemporary debate with his analysis aiming to demonstrate how human rights, perceived as normative guarantees against the state, actually participate in rendering human lives vulnerable to sovereign violence. Although Agamben joins some other critics, especially those influenced by Michel Foucault's work (for example, Wendy Brown), in making this claim, he radicalizes the critique of human rights in many ways. The critique is radical literally as it tries to grasp the problem by its roots. To do this, Agamben goes back to the early formulations of human rights in the eighteenth-century declarations, especially the 1789 Declaration of the Rights of Man and Citizen, and shows how these declarations reiterate the biopolitical fracture between political and natural life at the heart of Western metaphysics and politics. Once these declarations make life the foundation of the nation-state, every aspect of life becomes politicized and is subjected to sovereign power to an unprecedented degree. This analysis showing how human rights participate in the reproduction of a centuries-old problem takes Agamben also to a conclusion that is much more radical than those drawn by other critics: Given the underlying assumptions of human rights, there is no possibility of thinking them anew; we instead need to imagine a politics beyond human rights so as to sever the tight link that holds human life in the grip of sovereign power.

This article aims not only to understand Agamben's distinctive intervention in the contemporary debates on human rights but also to assess his concluding call for a politics beyond human rights. I argue that this call is necessitated by a counternarrative of Western politics that ties human rights inextricably to the 'logic' Agamben ascribes to biopolitical sovereignty. Within this stringent logic, any human rights struggle cannot help but participate in the reproduction of the sovereign violence that it aims to contest. The article questions this conclusion in two ways: First, it shows how Agamben's counternarrative, which aims to demystify all the myths that sustain sovereignty, ends up repeating what it identifies as the distinctive mythologizing gesture: rendering the contingent necessary. Albeit unwittingly, Agamben's narrative against Western myths reintroduces a 'principle of fated necessity', to use a phrase invoked by Max Horkheimer and Theodor Adorno to capture the 
problems of a mythologizing gesture that casts each event as an inevitable reinstatement of what always was $(2002$, p. 8$)$. Second, the article also shows how this gesture is at odds with Agamben's own efforts to rethink the past in terms of contingencies and inexhaustible potentialities. I argue that Agamben's rethinking of 'potentiality' as a capacity that is not consumed in any of its determinate actualizations can provide us with a better framework for capturing the contingent, complex and unfinished histories of sovereignty and rights.

The critical evaluation of Agamben in this article aims to proceed in the mode of an immanent critique understood in its broad sense: Instead of contesting Agamben's counternarrative by constructing an alternative historical account or by resorting to the conceptual resources of other theoretical traditions - two major routes taken by his critics - I intend to read Agamben against Agamben. ${ }^{1}$ Taking into account the tensions in Agamben's critique, I deploy his own terms (for example, potentiality) to contest some of his arguments and conclusions about human rights.

The article has four main sections: The first section examines the theoretical underpinnings of Agamben's analysis of sovereignty and biopolitics to provide a background for his critique of human rights. In the second section I analyze Agamben's arguments about human rights and underscore their distinctive dimensions, especially by showing how they draw on and yet differ from the Foucauldian critique. The third section criticizes Agamben's call for a politics of human rights, and shows how this call relies on a questionable reading that erases contingencies and complexities in the histories of human rights (and sovereignty). Finally, I turn to Agamben's own notion of 'potentiality' to offer an alternative understanding of human rights. To illustrate the promises of this alternative, I conclude with a brief analysis of the contemporary rights struggles of sans-papiers and assess the strengths and limits of Agamben's critique.

\section{Bare Life at the Intersection of Biopower and Sovereignty}

In 1998 France introduced an amendment to its law on the "Conditions of Entry and Residence of Foreigners'. This legal amendment granted residency permits to non-citizens who have 'life-threatening' pathologies that would not be properly treated if they were to be deported to their home countries (Ticktin, 2006). The amendment was motivated by humanitarian concerns; indeed, it was groups such as Médecins sans Frontières that pushed for such a legal change. This humanitarian provision, aiming to care for the suffering body, however, had some unanticipated and paradoxical effects: Introduced at a time when strict asylum and immigration policies made it increasingly 
difficult for non-citizens to legally reside in France, this illness clause was indeed one of the few options for securing basic rights. Yet, as Miriam Ticktin (2006) underscores, troubling effects of this humanitarian provision came to the fore shortly: increasing number of undocumented immigrants started to infect themselves with HIV, rejected treatment for illnesses such as cataract, or took on the identity of people with AIDS to be able to get residence permits.

This disconcerting case, illustrating how humanitarian politics aiming to care for life can have the paradoxical effect of producing disabled and infected bodies, provides significant insights into the pertinence of Agamben's account of sovereignty in the current political context. Particularly in Homo Sacer, Agamben argues that sovereignty consists in a decision over life, which always produces bare lives vulnerable to violence. One of the most controversial claims he makes is that human rights and humanitarianism, usually conceived as normative setbacks to sovereign power, actually work in ways to reinscribe it. They do this precisely by valorizing life and turning it into a site of political decision. In the case of the humanitarian provision in France, for instance, to be able to grant residence permits on the basis of 'life-threatening' pathologies, there needs to be a decision about what 'life' is in the first place (Ticktin, 2006, p. 42). These vital decisions and their effects are at the center of Agamben's analysis of the inimical effects of a politics centered on sovereignty and human rights. Below I will outline Agamben's analysis of biopolitical sovereignty to provide the groundwork for a discussion of his critique of human rights.

To understand the insidious effects of a power that makes the care of life its central task, Agamben draws on the work of Michel Foucault. Of particular interest is Foucault's contention that in modernity we see the emergence of biopower, which differs from the archaic sovereign power that relies on the threat of death and is instead centered on regulating and managing the biological life of the individual and species (Foucault, 1988, p. 143; 2003, p. 241). Contra Foucault, Agamben argues that biopower is not a distinctively modern form of power but is always already implicated in sovereignty (Agamben, 1998, pp. 6, 9). It is the type of power at work not only in modern democracies but also in absolute monarchies. To the extent that sovereignty, in its archaic and modern forms, always consists in a decision on life, it is indeed inseparable from biopower. ${ }^{2}$

Agamben starts off his analysis of this intersection between sovereignty and biopower with the premise that 'the production of a biopolitical body is the original activity of sovereign power' (1998, p. 6; emphasis in the original). As he works on this premise, he leaves aside Foucault's genealogy, and engages instead in a 'logico-formal' analysis that aims to delineate what is always already biopolitical in the permanent structure of sovereignty throughout Western politics (1998, p. 109). To do this, he draws on Carl Schmitt's 
definition of sovereignty as the decision on the exception (Agamben, 1998, pp. 19, 67, 83; Schmitt, 2005, p. 5). For both Agamben and Schmitt, sovereignty cannot ground itself in legal norms; it is in need of an 'exteriority' or 'factuality' to ground itself. To understand the relation between sovereign law and this exteriority, Agamben turns to the etymology of 'exception' (ex-capere), which indicates that sovereign exception is not merely exclusion; it is more precisely an 'inclusive exclusion', which signifies a double movement capturing at the very moment of excluding (1998, p. 21). On the basis of this etymology, Agamben argues that the logic of sovereignty consists in capturing, taking in, what is outside of the juridico-political order.

What is this 'exteriority' that is captured in sovereign law? The simple answer is 'life'. Agamben's reading of Schmitt suggests that law cannot have a concrete meaning without a relation to life (1998, p. 27). Drawing on Walter Benjamin, Agamben also concludes that this relationship between law and life always necessitates the isolation of a 'bare life' that can be killed with impunity. Life can be included in the sovereign sphere only in the form of an exclusion, or its capacity to be killed $(1998$, p. 8$)$.

To understand how 'bare life' is produced and to see how Agamben establishes the continuity of biopolitical sovereignty throughout Western history, it is important to look at his reading of the ancient Greek opposition between $z o \bar{e}$ and bios. According to Agamben, zoe refers to the 'simple fact of living common to all living beings (animals, men, or gods)' whereas bios denotes exclusively 'the form or way of living proper to an individual or a group' (1998, p. 1). Drawing on Aristotle's Politics, Agamben claims that this opposition underlies the exclusion of natural life from the polis and its relegation to the oikos $\left(1998\right.$, p. 2). ${ }^{3}$ It is this biopolitical division of political and natural life that always produces remainders and turns certain categories of living beings into 'bare life'. ${ }^{4}$ Bare life then is neither simple natural life of $z o \bar{e}$ nor politically qualified life of bios; rather it is the life produced as a result of sovereign decisions regarding what is distinctively human (1998, pp. 90, 106, 109).

By arguing that the 'inclusive exclusion' of life has been the permanent characteristic of biopolitical sovereignty, Agamben contests Foucault and argues that the novelty of modern biopolitics consists neither in the inclusion of $z o \bar{e}$ in the political sphere nor in the fact that politics is concerned with life (Agamben, 1998, p. 9). What is distinctive about modern power in this new account is that natural life, which was confined to the sphere of the oikos in the classical world, becomes the foundation of politics, and what used to be an exception - bare life - becomes the rule and comes to define the life of every citizen and human being, blurring the distinctions between polis and oikos, bios and $z o \bar{e}$, right and violence (1998, p. 9). As modern democracies dedicate themselves to the task of taking care of and protecting $z o \bar{e}$, they end up 
subjecting every aspect of life to sovereign power and turning each political subject virtually into bare life (1998, p. 111). Agamben attributes a significant role to modern juridico-political innovations such as habeas corpus and declarations of rights in this major historical transformation, and it is to these that I now turn to discuss Agamben's distinctive contribution to contemporary debates on human rights.

\section{Modern Rights Declarations and the Dissemination of Bare Life}

Agamben's analysis of modern juridico-political developments, including rights declarations, aims to reveal the inimical effects of the often-celebrated transformation of 'subject' into 'citizen' with the birth of modern democracy. He argues that with this transformation modern democracy does not abolish bare life but instead 'shatters it and disseminates it into every individual body' (1998, p. 125). With the introduction of habeas corpus, for example, modern democracy turns corpus or body into the new political subject (1998, p. 124), and repeats the biopolitical fracture at the heart of Western politics: it isolates a corpus, compels its physical presence before a court of law and renders it subject to the violence of sovereign decision. In Agamben's reading, habeas corpus is a harbinger of modern biopolitics, demonstrating that what lies in the modern passage from 'subject' to 'citizen' is not 'man as a free and conscious political subject but, above all, man's bare life' (1998, p. 128).

If habeas corpus introduces corpus as the bare life founding the body politic, modern rights declarations identify this body politic with the nation-state (1998, p. 127; 2000, p. 20). With these declarations, natural life, which was distinguished as $z o \bar{e}$ and relegated to the realm of oikos in the classical world, becomes the 'earthly foundation' of sovereignty in the modern nation-state (1998, p. 127; 2000, p. 20). Through a brief and provocative examination of the 1789 Declaration of the Rights of Man and Citizen, Agamben suggests that it is precisely bare natural life - which is to say, the pure fact of birth - that appears here as the source and bearer of rights' (1998, p. 127). He concludes that these rights declarations inaugurate modern biopolitics, in which bare life moves from the margins of the political order to its center.

Agamben's critique of modern rights declarations draws primarily on Hannah Arendt. Both authors take the problems of human rights, especially the precarious condition of refugees, as their starting point; instead of seeing these problems either as accidental incidents or implementation failures, they take them as symptoms revealing the deeply embedded paradoxes of human rights in a nation-state system. Of particular importance is the following conceptual dilemma at the heart of modern rights declarations: on the one hand, these declarations assume 'man' in his natural condition to be the source 
and bearer of rights that he is born with; on the other hand, they presuppose this man to be a 'citizen' with membership in a sovereign nation-state (Agamben, 1998, p. 128; Arendt [1951], 1973, p. 291).

Although both Arendt and Agamben have similar starting points, they proceed differently in their critiques and reach divergent conclusions. Arendt presents a more historically oriented inquiry, attending to the effects of important events such as the rise of imperialism on the conceptual paradoxes of human rights. She does not take the rightlessness of the stateless as an inevitable condition given the premises of modern rights declarations or given the conceptual dichotomies of Western metaphysics; instead, she treats it as a historically contingent problem that urges us to inquire into the paradoxes of human rights. Indeed, her critique ends with a call for rethinking, and not abandonment, of human rights (Arendt [1951], 1973, pp. 296-297).

Agamben, however, interprets the conceptual dilemma in rights declarations - that is, equivocal invocation of man and citizen - as another instance revealing the biopolitical fracture (bios/zōe) defining Western politics and metaphysics for centuries. Hence, he calls for nothing less than a politics that renounces all concepts, including human rights, which hold life in the grip of sovereign power. Indeed, in his account, far from disrupting the logic of biopolitical sovereignty, rights declarations aggravate its violence by politicizing natural life or $z o \bar{e}$. As modern democracy attempts to heal the biopolitical fracture between political and natural life by stipulating a fictional unity between man and citizen, birth (nascere) and nation, Agamben argues, it ends up turning virtually everyone into bare life (1998, p. 128). With these declarations, questions of inclusion and exclusion - that is, which man is a citizen? - become essentially political (1998, p. 131). These questions need to be constantly settled by sovereign decisions on the 'inclusive exclusions' of the national political community. As a result of these sovereign exceptions, there are various categories of people who inhabit the nation-state without being entitled to political rights (1998, p. 130).

As Agamben analyzes the effects of modern biopolitics inaugurated by rights declarations, he puts a particular emphasis on the crisis of the nation-state. Historical developments of early twentieth century, such as mass denationalizations, he argues, dissolved the fictional unity between birth and nation, man and citizen (1998, pp. 128). The crisis of the birth-nation link, however, does not end the politicization of natural life; indeed, it intensifies this process. One of the problematical effects of this crisis is the increasing deployment of human rights outside the context of citizenship as can be seen in modern humanitarianism; as human rights are dissociated from citizenship, they come to stand for the rights of those who are isolated as bare life - for example, refugees (1998, pp. 131-34; see also Fassin, 2005). Another effect of the dissolution of the fictional unity between birth and nation is the regulation and 
administration of life in the name of its valorization to an unprecedented degree. Once the fictional unity loses its 'mechanical force and power of self-regulation', nation-states need more than ever to be engaged in sovereign decisions discriminating between 'a so-to-speak authentic life and a life 1 acking every political virtue' (1998, p. 132). One of Agamben's most controversial claims is that these decisions, the lethal consequences of which became most explicit with modern eugenics and concentration camps, need to be understood within the context of modern biopolitics inaugurated by rights declarations that invest life with the principle of sovereignty: Life itself can become 'the place of a sovereign decision' only because it is politicized, valorized, and sacralized to an unprecedented degree in the first place (1998, p. 142).

At the end of his critical analysis of rights declarations, Agamben concludes that modern democracy has not only failed in healing the biopolitical fracture but also repeated it in an unprecedented fashion precisely by valorizing life. Modern rights declarations have turned 'the care of nation's biological body' into an essentially political task as they have attributed the principle of sovereignty to life (1998, p. 142). Insofar as these declarations have made it possible for the sovereign state to extend its regulative powers into every sphere of life, they have become complicit in the production of bare life.

In many ways, Agamben's analysis of human rights and humanitarianism resonates with the criticisms offered by several other contemporary scholars, especially those drawing on Foucault's work on governmentality. Agamben shares the Foucauldian insight that rights are not protective shields protecting subjects against sovereign power; indeed, the more we invoke rights, the more entangled we become with sovereign power. A recent example of this critical perspective can be seen, for example, in Wendy Brown's analysis of the discourse of human rights. Contesting prevailing conceptions of human rights as 'an antipolitical and expressly moral antidote to abusive political power', Brown underscores how this discourse works indeed as a form of political power when it constitutes us as subjects in need of protection and undermines political projects of collective empowerment (Brown, 2004, p. 454). This point is also emphasized in Brown's earlier work demonstrating that, far from helping us fight powerlessness, rights discourse can produce us as powerless victims as it can 'codify within the law the very powerlessness it aims to redress' (Brown, 1995, p. 21). Both Agamben and Brown would agree that human rights produce the very subjects that they presuppose and render their subjects vulnerable to sovereign power.

Although Agamben shares some of the premises of the Foucauldian critique, he differs from it at least in two ways. First, Agamben reintroduces a form of sovereign violence that seems almost anachronistic in an age of governmentality (Butler, 2004, p. 54). From a Foucauldian perspective, human rights 
are problematic, first and foremost, as tactics of governmentality used in the regulation and management of populations; attending to subtle forms of subject production, Foucauldian critique alerts us to a new form of biopower that is at work at a time when the archaic sovereign power over life and death is in decline. For Agamben, who precisely aims to look into the intersection of sovereignty and biopower, human rights participate in the production of a type of sovereign violence that Foucault assumed to be in decline (though not completely extinct). By making life itself the place of sovereign decision, human rights have paved the way for practices that increasingly blur the line between biopolitics and thanatopolitics, or between politics of life and politics of death (1998, p. 122). In contemporary politics valorizing life, Agamben's analysis suggests, the putatively archaic sovereign 'right to take life' merges perniciously into the new 'right to intervene to make life' (Foucault, 2003, p. 248).

Agamben's account, which turns our attention to the lives irredeemably exposed to sovereign violence, achieves an eerie pragmatic soundness with cases such as the French humanitarian provision that paradoxically ended up abandoning life at the 'no-man's land' between life and death, right and violence (Agamben, 1998, p. 90). The current global political context in which we can no longer be dismissive of such cases as mere exceptions to be remedied on the way to a more universal conception of human rights points to the crucial contribution of Agamben to the debates on human rights.

Agamben's work differs from the Foucauldian critique also in its call for abandoning human rights altogether in order to sever the link between life and sovereign power. From a Foucauldian perspective, it is still possible to rethink rights and invoke them in ways contesting sovereign power. For example, despite her criticisms of identity-based rights claims, Wendy Brown urges a rethinking of the democratic power of rights - a rethinking that moves away from the prevailing conception of rights as remedies for injuries suffered by particular groups to a more radical democratic conception focusing on the '(fictional) egalitarian imaginary' created by rights discourse (Brown, 1995, p. 133; see also Brown, 2000). ${ }^{5}$ For Agamben, however, there is no such possibility, precisely because human rights are inextricably tied to sovereign violence, given their reproduction of the biopolitical fracture between bios and $z o \bar{e}$ since their original formulations in the 1789 Declaration of the Rights of Man and Citizen.

This second point forms the linchpin of my critical engagement with Agamben: although Agamben persuasively argues for a critical inquiry that looks into the paradoxically violent effects of the human rights discourse, his concluding call for a 'politics beyond human rights' remains questionable, and as I will show, is at odds with his own attempts to understand history in terms of contingencies and potentialities (2000, pp. 15-26). From Agamben's 
standpoint, precisely because human rights are doomed to reproduce sovereign violence, any struggle for rights seems to be futile:

It is almost as if, starting from a certain point, every decisive political event were double-sided: the spaces, the liberties, and the rights won by individuals in their conflicts with central powers always simultaneously prepared a tacit but increasing inscription of individuals' lives within the state order, thus offering a new and more dreadful foundation for the very sovereign power from which they wanted to liberate themselves. (1998, p. 121)

This quote illustrates why Agamben's call for a politics beyond human rights needs to be critically examined. On the one hand, Agamben points to the 'double-sided' nature of modern political events. Given this acknowledgment, one can assume, events such as the institution of modern sovereignty or rights declarations have multiple, paradoxical and unpredictable effects. On the other hand, although Agamben notes the ambivalent nature of modern political events, he exclusively focuses on one dimension: the increasing subjection of human life to biopolitical violence of sovereign power. In what follows, I question this conclusion, which fails to attend to the multifarious, ambivalent and unpredictable effects of human rights. Of particular importance is the foreclosure of the possibility that rights can be reappropriated by political actors, particularly by those who have been relegated to bare life, to contest biopolitical divides. This conclusion, I suggest, runs counter to Agamben's own efforts to rethink 'potentiality' so as to redeem the contingencies of the past. Before making this argument, however, it is important to understand why and how Agamben's analysis disallows this possibility.

\section{Agamben's Counternarrative and the Problem of Mythologization}

In his analysis of biopolitical sovereignty, Agamben provides us with what might be called a counternarrative of Western politics with the explicitly stated goal of 'unveiling' or 'unmasking' what has become mystified, hidden, secret or invisible, particularly with the prevalence of contractarian accounts of political power (1998, p. 8; 2005, p. 88). Agamben describes this critical task in terms of 'disenchantment', or the 'patient work' of unmasking the fiction or myth that covers up and sustains the violence of sovereignty (2005, p. 88). What underlies this urge to demystify and unveil is a particular understanding of myth as a deceptive narrative naturalizing and legitimizing violence in the name of the preservation of life. 
I use the term 'counternarrative' to call attention to what Agamben's account aims to do $^{6}$ : This is a critical analysis, as Agamben himself insists, that does not offer 'historiographical theses or reconstructions' but instead treats some historical phenomena as 'paradigms' so as to 'make intelligible a broader historical-problematic context;' to do this, it proceeds at 'a historicophilosophical level' $(1998$, p. 11; 2009, p. 9). In that sense, it is not an account that claims historical accuracy or factual verifiability. This is a crucial point that is sometimes overlooked by Agamben's critics who call into question his inaccurate treatment of historical phenomena such as the concentration camps. ${ }^{7}$ In addition, 'counternarrative' draws our attention to the inventive dimensions of Agamben's endeavor; as one of his critics aptly (though disapprovingly) puts it, 'Agamben does not discover a concealed biopolitical paradigm stretching back to fourth-century Athens; rather he invents one' (Finlayson, 2010, p. 116). The invention of a counternarrative of Western politics involves literary devices (e.g. hyperbole), which aim to provoke the readers and persuade them to abandon any politics centered on modern concepts such as sovereignty, rights and citizenship (LaCapra, 2007; cf. de la Durantaye, 2009).

In analyzing Agamben's account as a 'counternarrative', I aim to attend to the goals that it sets for itself. It is these goals - particularly the goal of freeing human potentialities from myths that render the contingent necessary and mask other possibilities - that provide the starting point for my critical engagement with Agamben. Instead of resorting to an 'outside' - whether this be an alternative historical account or another theoretical tradition - I aim to read Agamben on his own terms, and suggest that as he tries to free human potentialities from contractarian myths, he might be entrapping them in another myth that ends up casting the contingent as necessary.

Agamben's counternarrative of Western politics aims to uncover what has become hidden or invisible with 'our modern habit of representing the political realm in terms of citizens' rights, free will, and social contracts' (1998, p. 106). Its main target is the contractarian accounts of sovereign power. As he identifies the production of bare life as the originary or foundational activity grounding sovereign power (1998, pp. 6, 83), he particularly aims to question the social contractarian 'myth' that covers up sovereign violence (1998, p. 109).

After unveiling the foundational myths of Western politics, Agamben concludes that we cannot effectively respond to "the bloody mystification of a new planetary order' if we let these myths continue to obstruct our political imagination (1998, p. 12). With his counternarrative presenting a catastrophic view of the historical present - a view that emphasizes how exception has become the rule, camp has become the paradigmatic structure organizing political space, and we have all virtually become homines sacri $(1998$, pp. 38, $176,111)$ - Agamben aims to convince his readers of the need to think of a 
'nonstatal and nonjuridical politics and human life' (2000, p. 112). This new politics requires the renunciation of concepts associated with sovereignty - for example, state, rights, citizenship. The contemporary predicament cannot be remedied by a return to conventional political categories and institutions, Agamben suggests, since these are deeply involved in the creation of this catastrophe in the first place. Almost anticipating his critics who would be puzzled by his renunciation of rights and rule of law at a time when the problem of legal dispossession increasingly threatens populations around the world, he explicitly states that the response to the current permanent state of exception cannot consist in confining it within constitutional boundaries and reaffirming the primacy of legal norms and rights (2005, p. 87). ${ }^{8}$ As legal norms and rights are ultimately grounded in the originary violence of separating a bare life, legal dispossession is already inscribed in them as an inescapable condition. Neither the liberal remedy of reasserting the rule of law, nor the Derridean strategy of 'infinite negotiations' with a law that is in force without any significance, are viable options $(2005$, p. 87; 1998, p. 54). Both are futile, if not lethally dangerous, endeavors. ${ }^{9}$ The only politically tenable option, Agamben contends, is to move out of sovereignty with 'a complicated and patient strategy' of getting the 'door of the Law closed forever' (1998, pp. 54, 55).

Agamben's counternarrative, which aims at the 'disenchantment' of social contractarian myths, ties human rights, citizenship, and sovereignty so inextricably to what he deems to be the permanent logic of biopolitics that any political strategy short of exodus becomes indefensible (2005, p. 88). As Agamben lifts the veil of the myths of sovereignty and invites us to join the patient work of inventing a new politics, however, does he end up constructing another myth of origins that is as enchanting and mystifying as those he aims to uncover? In invoking this possibility, I am deploying 'myth' in the sense implied by Agamben's account - that is, a deceptive narrative that casts what is contingent as inevitable and necessary. Agamben's counternarrative risks becoming another myth to the extent that it ultimately obscures the contingencies and possibilities in the complex histories of sovereignty and human rights.

It is Agamben's attempt to find out the 'logic' of sovereignty that entraps his counternarrative in mythology and is in tension with his project of demystification that aims to bring out the contingency of what has been justified as necessary. ${ }^{10}$ As mentioned above, the central task that Agamben's counternarrative sets for itself is the delineation of the 'formal structure' or 'logic' of sovereignty as it manifests itself across different spatiotemporal contexts in Western politics (1998, pp. 19, 67, 83). The identification of this 'logic' endows Agamben's counternarrative with continuity so that it can speak to '24 centuries' of Western politics $(1998$, p. 11). The paralyzing result of this 
move can be seen in his statements such as 'the river of biopolitics that gave homo sacer his life runs its course in a hidden but continuous fashion' throughout the history of Western politics (1998, p. 121; emphasis mine).

Agamben's counternarrative becomes one of 'fated necessity' as the 'logic' he attributes to sovereignty glosses over the ambivalences, discontinuities and unpredictabilities of its history. In doing this, the counternarrative cannot help but repeat, albeit unwittingly, the distinctive gestures that Agamben associates with 'myth': What was contingent seems as if it was necessary and inevitable. In the words of Horkheimer and Adorno, who analyzed how an anti-mythical posture itself can turn into myth, 'this barren wisdom merely reproduces the fantastic doctrine it rejects: the sanction of fate which, through retribution, incessantly reinstates what always was. Whatever may be different is made the same' (2002, p. 8). Only within the confines of Agamben's stringent logic, can any politics organized around sovereignty and human rights not help but reinscribe the originary violence repeated since the beginning of Western political history. The imposition of such a logic, which ends up imputing a preordained trajectory to any politics organized around sovereignty and human rights, however, is at odds with Agamben's own efforts to understand time and history in terms of inexhaustible potentialities. Indeed, Agamben's notion of 'potentiality' might help us break the binding spell of his own myth.

\section{Potentialities of Human Rights}

Agamben develops his distinctive notion of a potentiality that is not consumed in its determinate actualizations by critically engaging with Aristotle. In Book theta of Metaphysics, Aristotle argues against the Megarians who identify potentiality with actuality to the extent of denying any potentiality that is not actualized. The Megarian position, Aristotle suggests, would take us to the unreasonable conclusion that a builder has a potentiality for building only when he engages in the act of building and that he is not a builder when he is not building (Aristotle, 1998, p. 258). One of the major reasons why Aristotle resists the Megarians' denial of potentialities that are not actualized is that this would bring all movement, change, and becoming to a paralyzing stasis: 'So our brilliant Megarian friends will now have done away with all process and generation! The standing will remain on their feet, and the seated on those places where the Megarians keep their brains to eternity' (Aristotle, 1998, p. 259). To resist this indistinction between potentiality and actuality, Aristotle insists on understanding potentiality in terms of not only dynamis, or a power to become, be, or actualize, but also adynamia, or a power not to become, be, or actualize (Agamben, 1998, pp. 45-46; 1999, pp. 184). 
Aristotle's critique of the Megarians and his notion of a 'potentiality-not-to' are crucial for understanding Agamben's own attempts to think of a potentiality that is not annulled or destroyed in any of its determinate actualizations. For potentiality to have 'its own consistency', Agamben argues, it should not 'disappear immediately into actuality' (1998, p. 45). However, from Agamben's perspective, Aristotle falls short of giving potentiality its full due as he still privileges actuality, being and presence (Johnson, 2007, p. 285). Indeed, Agamben identifies in Aristotle's notion of 'potentialitynot-to' the metaphysical origins of the sovereign ban. Aristotle's formulation of a potentiality that maintains itself in the form of withdrawal or suspension comes very close, at least in Agamben's peculiar reading, to the ban structure in the Schmittian sovereign exception in which the law subjects life to its power precisely by way of suspension or withdrawal (Whyte, 2009, p. 315). Agamben's goal then becomes to uncouple potentiality from the sovereign ban by refusing to tie it to any notion of being and presence.

Agamben's ontological reflections, especially his efforts to rethink potentiality, have been carefully analyzed by other scholars (de la Durantaye, 2000, p. 16; Gulli, 2007, p. 223; Whyte, 2009, pp. 318-319). What is crucial for the purposes of my argument is that, as Agamben reappropriates Aristotle's potentiality-not-to, he sets himself a task that is at odds with the narrative of fated necessity that shapes his counternarrative of Western politics. Agamben's goal in rethinking potentiality is precisely to understand history in terms of contingency. In doing this, he counters two traditional principles 'the irrevocability of the past' and 'conditioned necessity' - that are invoked to annul the contingencies of the past (Agamben, 1999, p. 262). The principle of 'irrevocability' contends that the potentialities of the past cannot be realized retroactively, presenting what happened as complete and overlooking the possibility that things could have happened otherwise; it presents us with 'an impossibility of realizing the potentiality of the past' (1999, p. 262). The principle of 'conditioned necessity' sees future events as necessary occurrences, cancelling again the contingencies in the past (1999, p. 262). Agamben argues against both of these principles and rethinks the past in terms of multiple possibilities that can be repotentialized by actors in different settings. Hence, his notion of potentiality suggests that no past event is a 'simple element in a historical archive but a potentially dynamic means of understanding - and changing - the present situation' (de la Durantaye, 2009, p. 245).

I suggest that Agamben's efforts to rethink potentiality so as to redeem the contingencies of the past can actually be a more promising way to interpret the complex, multiple histories of human rights - one that can also question the narrative of fated necessity he attributes to rights struggles. This interpretation, guided by Agamben's insights into the 'potentialization' of the past, recasts rights struggles as events with possibilities that are not fully consumed in any of 
their determinate actualizations (Agamben, 1999, p. 267). To illustrate how understanding potentiality in its full inexhaustibility can help us reclaim the indeterminable temporality of human rights, I want to examine briefly the contemporary rights struggles of sans-papiers.

In 1996, a group of sans-papiers (literally, without papers, undocumented) occupied various churches to protest the administrative decrees that put them in a legal limbo. Their most memorable occupation at the Church of St Bernard in Paris ended with their forceful eviction by police forces. ${ }^{11}$ In November 1998, Madjiguène Cissé, a leading spokesperson of the sans-papiers, lodged an application with the European Court of Human Rights, complaining that her right to freedom of peaceful assembly, guaranteed under Article 11 of the European Convention of Human Rights (ECHR), was infringed by the forceful eviction. The Court agreed with Cissé that the evacuation amounted to an interference with the exercise of freedom of assembly. However, the Court added, 'the interference pursued a legitimate aim: the prevention of disorder'. In conclusion, 'although it regretted the sudden and indiscriminate manner in which the police intervened ... the Court found that the interference with the applicant's freedom of assembly was not disproportionate. Therefore there had not been a breach of Article 11' (Cissé v. France, 2002, p. 312).

This case manifests the strengths and limits of Agamben's biopolitical analysis. The Court decision clearly shows how sovereign exception continues to pervade human rights norms, challenging conventional accounts that see rights as normative restraints on sovereign power: freedom of assembly is codified in Article 11 of ECHR; yet, the exception clause of the same article allows states to impose restrictions on very ambiguous grounds, including 'national security or public safety', which can easily pave the way for arbitrariness (ECHR, Art. 11). The Court's justification of the forceful police eviction with references to sanitary conditions and strikers' health also confirms Agamben's argument that the valorization of life can indeed participate in the production of bare lives that can be exposed to sovereign violence.

If the forceful eviction and the Court decision were to exhaust the potentiality of the sans-papiers' struggle, we could have concurred with Agamben's concluding call for a politics beyond human rights. In doing that, however, we would also risk becoming contemporary Megarians, collapsing potentiality into actuality. Indeed, both the beginnings and the ongoing effects of sans-papiers movement are caveats against this position. The sans-papiers movement started its demonstrations on 18 March 1996, and it is interesting to note that it was on 18 March 1871 that the Paris Commune seized power in the city. 'March 18' holds a symbolic power in the political imaginary of the sans-papiers; a recurring slogan of the movement has been 'March 18, 1996, on c'est levé (we have risen)' (Ruggiero, 2000, p. 53). The event demonstrates that 
the potentiality of the Commune was not consumed in the summary executions, deportations and imprisonment of Communards, as its memory of a quite different understanding of 'sovereignty' (that is, the constitution of a self-governing, free political association) has been invoked by several political movements, including the sans-papiers, throughout history. Not only the beginnings but also the ongoing effects of the sans-papiers' mobilization reveal the need to understand political events as containing potentialities that cannot be consumed in their determinate actualizations. The forceful eviction did not end sans-papiers' demonstrations; it turned out to be just the beginning of a European-wide mobilization that continues to question the limits of existing conceptions of rights and citizenship.

Multiple, conflicting and unpredictable invocations of sovereignty and human rights in this particular case point to the need to come up with an assessment diverging from Agamben's call for a politics beyond them. In the court's deployment of sovereignty and human rights, we see an attempt to reinscribe biopolitical divisions exposing certain lives to an unpunishable violence (yet this is by no means an unrisky attempt, as it also involves a critique of the extremity of the violence used). What survives this attempt, however, is a 'potentiality-not-to', indicating the possibilities of withholding the affirmation of such biopolitical divisions as well as contesting and transforming them. Such possibilities come to the fore in the sans-papiers' invocation of human rights in order to contest the 'clandestinity' imposed on them due to a lack of proper documentation. The words of Madjiguène Cissé are telling in this regard:

In France up until now our fate as immigrants was: either take part in the Republic's process of integration, or be deported like cattle. At the heart of this approach was the notion that we are 'underground', which has a very negative charge ... We have made ourselves visible to say that we are here, to say that we are not in hiding but we're just human beings. (Cissé, 2003, p. 43)

Clandestinity is indeed the condition forcing non-citizens without proper documentation to dwell, in Agamben's words, in a 'zone of indistinction' between politics and nature, bios and $z o \bar{e}$, human and non-human. At this threshold they are exposed to sovereign violence (that is, always ready to be deported as 'cattle'). Hence clandestinity is part and parcel of biopolitical sovereignty in its inclusive exclusion of a 'bare life': Sans-papiers are excluded from the political life, and yet they are also included since they are subject to the laws, and their exclusion founds, sustains and defines the political community. What escapes Agamben's biopolitical narrative, however, is the sans-papiers' contestation of their clandestinity, or their isolation as bare life, 
precisely by resignifying the constitutive terms of rights declarations - 'man' and 'citizen' - in their claims to human rights and democratic liberties (Cissé, 2003, p. 40).

Such reappropriations call attention to the problems of understanding rights declarations and struggles in terms of a narrative of 'fated necessity'. We can remember here Agamben's own characterization of rights declarations and struggles as 'double-sided' (1998, p. 121). As such, these declarations and struggles have multiple, equivocal and unpredictable effects. ${ }^{12}$ They do not merely reinscribe sovereign violence, as Agamben's account suggests, but they can also open up the possibilities of contesting 'inclusive exclusions' sustained by existing conceptions of rights, citizenship and sovereignty. Indeed, conceptual equivocations of modern rights declarations (for example, man/citizen, nature/ politics), taken by Agamben as another sign of the biopolitical fracture defining Western politics and metaphysics since antiquity, can enable such contestation: it is precisely this equivocal language that forecloses the possibility of any final authoritative interpretation and that can give rise to new appropriations. ${ }^{13}$

What struggles such as the sans-papiers point to are precisely the problems of two forms of fatalism that figure in contemporary assessments of human rights. On the one hand, there is the fatalistic position of those who turn to human rights in the name of a pragmatic minimalism and take them as our only hope to limit violence, suffering and cruelty in the global order. ${ }^{14}$ Then there is the other kind of fatalism, a version of which we see in Agamben's counternarrative of Western politics, in which sovereignty and human rights are doomed to leave us at the threshold of a catastrophe, and so we have no option but to abandon them. Neither of these fatalistic assessments captures the multiple and contingent effects of human rights (or sovereignty). If the first position is oblivious to how certain lives become unworthy and unliveable because of prevailing conceptions of sovereignty and human rights, the second forecloses an analysis of their unpredictable appropriations and ongoing transformations. Both forms of fatalism need to be questioned precisely to grapple with the indeterminable temporalities of human rights and sovereignty.

\section{Acknowledgements}

I am grateful to Çiğdem Çıdam for carefully reading several versions of this article. I would like to thank Mary Dietz, Bud Duvall, Bill Scheuerman, Bruce Braun, two anonymous reviewers and Sam Chambers for their insightful comments and suggestions. The article has benefited significantly from the feedback provided by the members of my writing groups at the University of Minnesota and Barnard College. An earlier version was presented at a 
conference on 'Second Nature' at the Northwestern University in February 2007, and I would like to thank the co-organizers Crina Archer, Laura Ephraim, and Lida Maxwell as well as the discussant of my panel Bonnie Honig for their helpful comments.

\section{Notes}

1 There is a vast secondary literature on Agamben's work, and it is impossible to provide here a comprehensive list of his critics - let alone capture the full complexity of their criticisms. Many, however, have resorted to conceptual resources of alternative theoretical traditions to contest Agamben. There are, for instance, several Foucauldian accounts that criticize Agamben's use and abuse of 'biopower'; see Fitzpatrick (2001), Genel (2006), Patton (2007). Furthermore, Agamben's account of 'potentiality' and 'power' has been subjected to critical scrutiny by Antonio Negri, who draws on Spinoza (Casarino and Negri, 2004; Negri, 2007). Agamben's analysis of 'sovereignty' has been criticized by William Connolly (2007), who turns to Tocqueville and Deleuze, and Andreas Kalyvas (2005), who draws on Plato. Finally, Agamben's analysis of human rights has been criticized by Deranty (2004), who invokes Hegel and Rancière, and Daly (2004), who resorts to a theory of natural rights.

2 For a critique of Agamben's reading of Foucault, see in particular Fitzpatrick (2001) and Genel (2006).

3 Finlayson (2010) offers a careful analysis showing the problems of reading bios/zoe as a dichotomous conceptual pair defining not only Aristotle's work but also the Greek polis.

4 For a further analysis, see Norris (2005).

5 Wendy Brown raises this possibility without fully developing it. Some scholars have critically engaged with Brown and explored this possibility at length; see, for example, Chambers (2004), drawing on Ernesto Laclau and Chantal Mouffe, in order to offer a radical democratic reconceptualization of rights, and Zivi (2005), for a performative account that relies especially on Judith Butler.

6 Deranty (2004) uses the term 'counternarrative' in his analysis of Agamben, though without fully exploring its methodological implications.

7 See in particular Mesnard (2004) and Mazower (2008). For a careful analysis (and defense) of Agamben's approach to history, see in particular de la Durantaye (2009, ch. 6).

8 For an analysis criticizing Agamben's post-statist move and insisting instead on the state, see Passavant (2007). For a critique of this strategy of reasserting institutions in response to Agamben, see Hussain and Ptacek (2000, pp. 511-512).

9 Agamben's critique of Derrida's approach to law can be seen especially in his alternative reading of Kafka's 'Before the Law' (1998, pp. 49-62 and 1999, pp. 170-172). For analyses of the differences between Agamben and Derrida, see particularly Mills (2004; 2008, pp. 121-122) and Thurschwell (2003).

10 William Connolly has also criticized Agamben for imposing a 'logic', constituted of 'ironclad paradoxes', on sovereignty (2007, p. 30). Although I do agree with the main arguments of Connolly's critique, I also want to add that the imposition of this 'logic' is indeed in tension with some of the premises of Agamben's own theory.

11 For analyses of sans-papiers, see, among others, Rosello (1998) and Ruggiero (2000).

12 For an insightful analysis of the unpredictable and plural temporalities of rights, see Honig (2009, pp. 55-56).

13 See, among others, Balibar (1994) and Rancière $(1999,2004)$ for a similar approach to rights.

14 For a critique of this minimalist and fatalistic pragmatism, see Brown (2004). 


\section{References}

Agamben, G. (1998) Homo Sacer: Sovereign Power and Bare Life, Translated by D. Heller-Roazen. Stanford, CA: Stanford University Press.

Agamben, G. (1999) Potentialities: Collected Essays in Philosophy, D. Heller-Roazen (ed. and trans.), Stanford, CA: Stanford University Press.

Agamben, G. (2000) Means Without Ends: Notes on Politics, Translated by V. Binetti and C. Casarino. Minneapolis, MN and London: University of Minnesota Press.

Agamben, G. (2005) State of Exception, Translated by K. Attell. Chicago, IL: University of Chicago Press.

Agamben, G. (2009) The Signature of All Things: On Method, Translated by L. Di Santo and K. Attell. New York: Zone Books.

Anderson, P. (2002) Force and consent. New Left Review 17: 5-30.

Arendt, H. ([1951], 1973) The Origins of Totalitarianism. New York: Harcourt.

Aristotle (1998) The Metaphysics, Translated by H. Lawson-Tancred. London and New York: Penguin.

Balibar, É (1994) Masses, Classes, Ideas: Studies on Politics and Philosophy Before and After Marx. New York and London: Routledge.

Brown, W. (1995) States of Injury: Power and Freedom in Late Modernity. Princeton, NJ: Princeton University Press.

Brown, W. (2000) Revaluing critique: A response to Kenneth Baynes. Political Theory 28(4): 469-479.

Brown, W. (2004) 'The most we can hope for...': Human rights and the politics of fatalism. South Atlantic Quarterly 103(2/3): 451-463.

Butler, J. (2004) Precarious Life: The Powers of Mourning and Violence. London and New York: Verso.

Casarino, C. and Negri, A. (2004) It's a powerful life: A conversation on contemporary philosophy. Cultural Critique 57: 151-183.

Chambers, S. (2004) Giving up (on) rights? The future of rights and the project of radical democracy. American Journal of Political Science 48(2): 185-200.

Cissé v. France. (2002) Human Rights Case Digest 13(3-4): 311-313.

Cissé, M. (2003) The sans-papiers: a woman draws the first lessons. In: Notes From Nowhere (ed.), We Are Everywhere: The Irresistible Rise of Global Anticapitalism. London and New York: Verso, pp. 38-45.

Connolly, W. (2007) The complexities of sovereignty. In: M. Calarco and S. DeCaroli (eds.), Giorgio Agamben: Sovereignty and Life. Stanford, CA: Stanford University Press, pp. 23-42.

Daly, F. (2004) The non-citizen and the concept of 'human rights'. borderlands, e-journal 3(1), http://www.borderlands.net.au/vol3no1_2004/deranty_agambnschall.htm, accessed 18 September 2004.

de la Durantaye, L. (2000) Agamben's potential. Diacritics 30(2): 3-24.

de la Durantaye, L. (2009) Giorgio Agamben: A Critical Introduction. Stanford, CA: Stanford University Press.

Deranty, J. (2004) Agamben's challenge to normative theories of modern rights. borderlands, e-journal 3(1), http://www.borderlands.net.au/vol3nol_2004/deranty_agambnschall.htm, accessed 18 September 2004.

Douzinas, C. (2007) Human Rights and Empire: The Political Philosophy of Cosmopolitanism. Abingdon, Oxford, and New York: Routledge-Cavendish.

Fassin, D. (2005) Compassion and repression: The moral economy of immigration policies in France. Cultural Anthropology 20(3): 362-387.

Finlayson, J.G. (2010) 'Bare life' and politics in Agamben's reading of Aristotle. Review of Politics 72(1): $97-126$. 
Fitzpatrick, P. (2001) These mad abandon'd times. Economy and Society 30(2): 255-270.

Foucault, M. (1988) History of Sexuality: Volume I: An Introduction, Translated by R. Hurley. New York: Vintage Books.

Foucault, M. (2003) 'Society Must Be Defended:' Lectures at the Collége de France, Translated by D. Macey. New York: Picador.

Genel, K. (2006) The question of biopower: Foucault and Agamben. Rethinking Marxism 18(1): 43-62.

Gullì, B. (2007) The ontology and politics of exception: Reflections on the work of Giorgio Agamben. In: M. Calarco and S. DeCaroli (eds.), Giorgio Agamben: Sovereignty and Life. Stanford, CA: Stanford University Press, pp. 219-242.

Honig, B. (2009) Emergency Politics: Paradox, Law, Democracy. Princeton, NJ and Oxford, UK: Princeton University Press.

Horkheimer, M. and Adorno, T.W. (2002) Dialectic of Enlightenment: Philosophical Fragments, Translated by E. Jephcott. Stanford, CA: Stanford University Press.

Hussain, N. and Ptacek, M. (2000) Thresholds: Sovereignty and the sacred. Law and Society Review 34(2): 495-515.

Johnson, D.E. (2007) As if the time were now: Deconstructing Agamben. South Atlantic Quarterly 106(2): 265-290.

Kalyvas, A. (2005) The sovereign weaver: Beyond the camp. In: A. Norris (ed.), Politics, Metaphysics, and Death: Essays on Giorgio Agamben's Homo Sacer. Durham, NC and London: Duke University Press, pp. 107-134.

Kennedy, D. (2002) The international human rights movement: Part of the problem? Harvard Human Rights Journal 15: 101-125.

LaCapra, D. (2007) Approaching limit events: Siting Agamben. In: M. Calarco and S. DeCaroli (eds.), Giorgio Agamben: Sovereignty and Life. Stanford, CA: Stanford University Press, pp. 126-162.

Mazower, M. (2008) Foucault, Agamben: Theory and the Nazis. boundary 2 35(1): 23-34.

Mesnard, P. (2004) The political philosophy of Giorgio Agamben: A critical examination. Totalitarian Movements and Political Religions 5(1): 139-157.

Mills, C. (2004) Agamben's messianic politics: Biopolitics, abandonment and happy life. Contretemps 5: 42-62.

Mills, C. (2008) The Philosophy of Agamben. Montréal, Canada: McGill-Queen's University Press.

Mutua, M. (2002) Human Rights: A Political and Cultural Critique. Philadelphia, PA: University of Pennsylvania Press.

Negri, A. (2007) Giorgio Agamben: The discreet taste of the dialectic. In: M. Calarco and S. DeCaroli (eds.), Giorgio Agamben: Sovereignty and Life. Stanford, CA: Stanford University Press, pp. 109-125.

Norris, A. (2005) Introduction: Giorgio Agamben and the politics of the living dead. In: A. Norris (ed.), Politics, Metaphysics, and Death: Essays on Giorgio Agamben's Homo Sacer. Durham, NC and London: Duke University Press, pp. 1-30.

Passavant, P. (2007) The contradictory state of Giorgio Agamben. Political Theory 35(2): 147-174.

Patton, P. (2007) Agamben and Foucault on biopower and biopolitics. In: M. Calarco and S. DeCaroli (eds.), Giorgio Agamben: Sovereignty and Life. Stanford, CA: Stanford University Press, pp. 203-218.

Rancière, J. (1999) Dis-agreement: Politics and Philosophy, Translated by J. Rose. Minneapolis, MN: University of Minnesota Press.

Rancière, J. (2004) Who is the subject of the Rights of Man? South Atlantic Quarterly 103(2/3): 297-310.

Rosello, M. (1998) Representing illegal immigrants in France: From clandestins to l'affaire des sans-papiers de Saint-Bernard. Journal of European Studies 28: 137-151. 
Ruggiero, V. (2000) The fight to reappear. Social Justice 27(2): 45-60.

Schmitt, C. (2005) Political Theology: Four Chapters on the Concept of Sovereignty, Translated by G. Schwab. Chicago, IL: University of Chicago Press.

Ticktin, M. (2006) Where ethics and politics meet: The violence of humanitarianism in France. American Ethnologist 33(1): 33-49.

Thurschwell, A. (2003) Specters of Nietzsche: Potential futures for the concept of the political in Agamben and Derrida. Cardozo Law Review 24: 1193-1259.

Whyte, J. (2009) 'I would prefer not to': Giorgio Agamben, Bartleby and the potentiality of the law. Law and Critique 20(3): 309-324.

Zivi, K. (2005) Feminism and the politics of rights: A qualified defense of identity-based rights claiming. Politics and Gender 1(3): 377-397. 